\title{
4. Continuity and change in the outer public sector
}

\author{
ROGER WETTENHALL
}

\section{Introduction}

This chapter continues the record of changes in the outer public sector carried through all previous volumes in the Australian Commonwealth Administration series. As in all previous volumes, here the 'outer public sector' is conceived of as that part of the public sector that is made up of non-departmental public bodies (NDPBs) - a broad category comprising mainly statutory authorities and corporations, government-owned companies and executive agencies, all of which fall outside the central establishment of ministerial departments and a few parliamentary departments. The word 'quango' is sometimes used as an alternative general class name.

A difficulty with all relevant classification exercises is, however, that the NDPB category does not lend itself to the drawing of clear boundaries. If we envisage the public sector as a wheel-like structure containing an inner area made up of the departments with their policy, system-maintaining and some operational functions, and an outer area made up of all the non-departmental bodies performing operating, regulatory and other system-serving functionssometimes thought of as constituting a large governmental 'fringe' - then there is opaqueness both between the inner and outer areas and at the far edge of the outer area. ${ }^{1}$

Such opaqueness occurs closer to the centre of government when some public functions are placed in divisions of departments that are sufficiently separately branded to have some of the characteristics of NDPBs. Closer to the outer fringes of government, it occurs in several ways. We find varieties of publicprivate mixing, with bodies in which the central government or an NDPB

1 The inner and outer areas as described here are sometimes referred to as 'core' and 'non-core'; however, I believe that terminology diminishes the importance of the outer area, so I avoid it in this chapter (except in quotations). 
shares ownership and operations with one or more non-governmental (private) bodies; these 'mixed enterprises' have traditionally been seen as parts of the outer public sector if the public stake comes to more than 50 per cent. And the mixing could rather be with 'non-government' in its other sense - that of the 'third sector' inhabited by a mass of not-for-profit bodies. Indeed, it is sometimes difficult to determine whether an organisation is an NDPB or a thirdsector body. Yet another set of boundary issues arises from the field of interjurisdictional sharing: some NDPBs are creations of two or more governments, so that reality is offended if we try to locate them in a single public sector. Examples of all these types of opaqueness are provided in the discussion below, which also notes other problems of terminology and classification in the NDPB arena.

Notwithstanding these difficulties of comprehension, virtually all governments have NDPBs. It has been widely observed that, though they might not be much liked, the processes of government could scarcely operate without them. Exploring this part of a public sector is an exercise in understanding how the machinery of government works and, as with earlier editions of the Australian Commonwealth Administration series, it is appropriate to begin this present exploration with an indication of changes that occurred in the establishment of the central departments in the transition from the Howard governments to the Rudd government. How NDPBs connect with this departmental establishmentas a class and individually - is always a central issue to be confronted in an exploration such as this.

Following a brief description of the departmental arrangements, this chapter goes on to consider issues of terminology, classification and general agency policy that have arisen in the NDPB experience of the Rudd government. The Uhrig Review of the Corporate Governance of Statutory Authorities and Office Holders and reactions to it (Uhrig 2003; Wettenhall 2005a, 2005b) came close to dominating the NDPB experience of the fourth Howard government. Necessarily, therefore, this chapter asks whether that fascination with Uhrig continued into the dispositions of the new government, or whether other forces took over as shapers of structures and relationships. The chapter also identifies the new creations, reorganisations and abolitions of the period and seeks generally to illustrate the pervasiveness of the population of NDPBs throughout the whole intertwined system of government, economy and society.

A general theme is that, while there have been many changes, the whole commonwealth experience with NDPBs during the Rudd government period suggests that the evolution of NDPB policy and practice mostly follows a line of continuous development over a much longer period. 


\section{The departmental establishment}

Whereas the last Howard government had 16 portfolios and corresponding portfolio departments with two other departments (Human Services and Veterans' Affairs) arranged as 'outliers' within one or other of the portfolio departments, the Rudd government began with 17 portfolios and portfolio departments and two outlier departments (Climate Change and Veterans' Affairs). Several of the Howard portfolios and portfolio departments continued as before, though with some redistribution among the departments of statutes administered-in particular, the Attorney-General's Department gained many new responsibilities as it inherited a range of additional statutes to administer relating to territories and to emergency services. Within the portfolio departments, most ministers were assisted by other ministers of non-cabinet $\operatorname{rank}^{2}$ and by parliamentary secretaries - for example: the Minister for Justice and Customs assisted the Attorney-General in the administration of that department and had a dedicated relationship with some of the NDPBs associated with it, which were described on the departmental web site as 'portfolio agencies'.

Appendix 4.1 lists the departments of the Rudd government and shows their relationship to those of the previous government. While a few of the listed titles have had very long lives (Attorney-General's and Treasury go back to the time of Federation), the Rudd list probably went further than that of any other commonwealth government in applying titles that reflect contemporary policy issues and associations (such as Broadband, Deregulation, Innovation and Climate Change - the last expanded late in the period to Climate Change and Energy Efficiency). It could be speculated that these titles reflected the initial enthusiasm to be different and tackle particular pressing problems, but that they would not endure long, leading to a sense of instability within the affected departments and their associated bodies.

For completeness, Appendix 4.1 also lists the parliamentary departments, though their involvement in the NDPB story is fairly limited; it does not go much beyond the existence of a Parliamentary Service Commissioner and the fact that the Public Accounts Committee, which the parliamentary departments service, has particular prescribed functions relating to the office of the AuditorGeneral.

2 Foreign Affairs and Trade is an exception, with two ministers of cabinet rank. 


\section{Away from the centre: terminology, classification and related issues}

\section{On underestimating the size and importance of the outer public sector}

The size of a total public sector and its importance for the economy and society of the state it serves are frequently underestimated by people at or near the centre of a governmental system - people such as politicians, administrators and commentators, who focus on the inner part as though it is all that really matters. And this underestimation often leads to the sometimes quite damaging assumption, when the outer part is finally remembered, that language, forms and principles applying appropriately to the inner apply equally appropriately to the outer. There are important distinctions and the machinery of government will not function as well as it might if they are not adequately recognised.

The first report of the Advisory Group on Reform of Australian Government Administration appointed by Prime Minister Rudd in mid-2009 illustrated this problem (Moran 2009). Consistently with 'whole-of-government' thinking, the group used the terms 'public sector' and 'public service' virtually interchangeably. Of course, the Public Service is part of the public sector, but it is only a part. In this sort of treatment, which has been very common recently, the needs and importance of the outer areas of the public sector inevitably suffer serious neglect. ${ }^{3}$

In preparing its second and final report, the Advisory Group apparently heeded criticism that it had been careless about such machinery-of-government matters (Gourley 2009; Wettenhall 2010). Now it focused appropriately on its central mission - the Public Service proper - with fairly sparse commentary about the rest:

Within Australian Government administration, the Australian Public Service (APS) is a core institution... Of the approximately 300,000 Australian Government employees, around 160,000 are employed in the APS...Remaining Australian Government employees operate under other Commonwealth agency specific legislation (such as The Australian Federal Police Act 1979), and those employed under other arrangements (for example Commonwealth companies such as Medibank Private Limited) who work closely with APS employees. (Moran 2010:viii, 3)

3 The Uhrig report, which played such an important role in the relevant history of the fourth Howard government, could not make this mistake because its terms of reference directed it specifically to NDPBs: statutory authorities and statutory office holders. 
There was a general exhortation that 'efficiency in the public sector is critical to ensure the best possible outcomes are achieved for the level of input'. Of course, the word 'agency' was used, but in adding that the search was for 'efficiency across the APS and within agencies' (Moran 2010:67), the implication was that the concern was with departments and those agencies staffed within the Australian Public Service. ${ }^{4}$ As will be noted elsewhere in this book, one major reform strategy was for a strengthening of the Public Service Commission to play a leadership role; however, as a former commissioner has noted under the intriguing title 'Inside or outside the tent' (Podger 2009:159-82), there are ambiguities about its governmental centrality and the notional autonomy that comes with its statutory authority status. Beyond that, in calling for '[e]fficiency in the creation of inter-jurisdictional entities; [a] governance framework that is efficient and promotes fit-for-purpose organisations... and [m]ore efficient small agencies' (Moran 2010:67), a final recommended reform strategy did come some way towards acknowledging the kinds of issues to which this chapter directs attention.

An item of international recognition secured late in the Rudd government period attested to the prestige that can come to members of the NDPB establishment. In the 2010 UN Public Service Awards competition, two accolades came to Australia: to the Australian Electoral Commission and the National Blood Authority (Ludwig 2010). Both are statutory authority members of this establishment, with the particular status of 'statutory agencies' (on which see below).

\section{Towards framework statutes}

The circumstance that some NDPBs are staffed as part of the Public Service and some are not contributes to the fairly general misunderstandings. Using a variant style of terminology, there are 'off-public service' NDPBs as well as 'on-public service' ones, just as there are 'off-budget' agencies as well as 'onbudget' ones. This has been accommodated in part by the development within the Commonwealth system since 1997 of the division between agencies subject to the Financial Management and Accountability (FMA) Act (they are part of the Commonwealth fiscus so 'on-budget') and those subject to the Commonwealth Authorities and Companies (CAC) Act (not part of the Commonwealth fiscus, with independent financing arrangements so 'off-budget'). ${ }^{5}$ With some exceptions, the on-public service/off-public service division corresponds with the onbudget/off-budget division. The 1997 statutes represent a culmination of efforts to establish some order in the management of the public sector as a whole that had been under way at least since the time of the Coombs Royal Commission,

4 Conflicting uses of the term 'agency' present another problem (see Wettenhall 2005b).

5 Though there may be budget interactions, as when governments buy some services from them, make grants or loans to them for particular purposes, or receive dividends and loan repayments from them. 
and it is a distinct improvement that the way of thinking it encourages is now widely established within the Commonwealth system. Unfortunately, the hardline advocates of whole-of-government 'solutions' to perceived problems of government often do not seem to understand the distinctions and the need for separate recognition of the outer parts.

The major organisational categories recognised in the two framework acts are as follows. ${ }^{6}$

\section{FMA Act}

- portfolio (ministerial) departments (in Department of Finance and Administration/Deregulation terminology: 'departments of state')

- parliamentary departments

- non-commercial statutory authorities, usually without boards, also called 'statutory agencies' when staffed under the Public Service Act

- executive agencies

- prescribed agencies (a category that includes the executive agencies and FMA-connected statutory authorities, but goes further to embrace some large departmental branches with considerable managerial autonomy; see further below).

\section{CAC Act}

- statutory authorities with separate fiscuses, usually incorporated with boards (so also statutory corporations)

- government-owned companies limited by guarantee

- government-owned companies limited by shares.

The Department of Finance and Administration/Deregulation (DoFA/DoFD) has provided a very useful service since 2003 in producing two-sided coloured 'flip charts' recording movement in these categories. It has also been producing a comprehensive List of Australian Government Bodies and Governance Relationships (DoFD 2009a) that goes much further in providing a detailed breakdown of each ministerial department, with information about branches, agencies and functions performed-extending to ministerial councils, intergovernmental bodies, joint ventures and partnerships, and much else. Though they thus cover much more, the lists provide useful data about the NDPB establishment.

DoFA entrenched its position as machinery-of-government nerve centre for the Commonwealth administration when it provided the secretariat for the Uhrig inquiry during the fourth Howard government. It subsequently provided

6 As discussed below, for one reason or another, a few Commonwealth entities have escaped inclusion under either system. 
enduring policy underpinning for the conceptual skeleton provided by Uhrig - it was well aware of the high level of criticism the Uhrig report had attracted (Uhrig 2003; Wettenhall 2005a:46) — by developing a set of guidelines for ministers and senior departmental officials considering the creation of new administrative bodies (DoFA 2005). This statement of governance arrangements was to prove highly influential when the system moved into new leadership under Rudd and Labor.

A major objective was to promote greater consistency and greater collaboration between departments in thinking about such developments. There was a presumption in favour of maintaining new functions within departments wherever possible and a further presumption that, where there was a strong case for a separate body, the FMA framework with employment under the Public Service Act was the preferred option. It was consistent with Uhrig and with whole-of-government thinking that agencies with high autonomy were to be used sparingly. The CAC framework came into its own where commercial-type activities and mixed-ownership activities were involved and corporate boards were deemed necessary - though there is a suggestion that, in the event, DoFD needed much persuading that CAC conditions were necessary even where mixed ownership applied. ${ }^{7}$

The government arrangements statement contained one significant reversal. Fuelled by 'New Public Management' (NPM) influences, there had been a marked movement from the late 1980s away from the statutory-body form towards the company form, even where public ownership remained constant. Now, however - in a return to the policy enunciated in the Walsh policy guidelines of the Hawke period (Walsh 1986) - the presumption is that it is preferable to establish a body as a Commonwealth authority rather than as a Commonwealth company', and a company should be established only 'in exceptional circumstances' (DoFA 2005:xiv). ${ }^{8}$

This reversal was already apparent before the 2007 change of government, but some terminological confusion remained. Unfortunately for clear understanding of machinery-of-government issues, the popular language did not change much and press reporting often continued to describe statutory bodies erroneously as 'companies' (for examples of this treatment of Australia Post and CSIRO in just three days in the Canberra press, see Ja 2010; Mannheim 2010). It is likely that some confusion arose from a passage in the 2009 DoFD list in which three statutory bodies - Australia Post, CSIRO and Indigenous Business Australiawere referred to in a paragraph beginning with the words 'companies limited

7 In the case of the Australian Curriculum Assessment and Reporting Authority.

8 For a fairly similar earlier episode in which the criterion for exemption was stated as a 'necessity only, as opposed to convenience', see Wettenhall (1987a:37-8). The problem is, of course, that terms such as 'necessity' and 'exceptional circumstances' are incapable of precise definition. 
by shares'. The point being illustrated was not that they were companies themselves, but that each of them had a number of subsidiary bodies organised as companies (DoFD 2009a:vii).

The notion of 'prescribed agency' is another development of classificatory significance. Prescription is by regulation under the FMA Act and, as noted, the category includes executive agencies, statutory bodies other than those under the CAC Act and parts of departments considered to 'be legally or administratively independent to a level that justifies financial autonomy' (DoFA 2005:51). ${ }^{9}$ To complicate the picture, DoFD recognises two other kinds of quasiseparate parts of departments-'business operations' and 'functions with separate branding' - that nonetheless lack prescribed agency status. Examples of the three types of quasi-separate parts of departments drawn from the DoFD list are given in Appendix 4.2.

The organisational history of some of these entities reflects the opaqueness of the border between departments proper and non-departmental portfolio agencies. Thus the Australian Agency for International Development (AusAID) had a statutory authority forebear, the Australian Development Assistance Agency, for a short period in the 1970s (Viviani and Wilenski 1978), and statutory authority status has again been suggested for it from time to time; in the controversies affecting the Therapeutic Goods Administration in 2006, it was often assumed by the media - incorrectly - that it was 'an independent body' (Wettenhall 2007:72); and the Australian Government Information Management Office was an executive agency for a short period after 1999. To the unofficial observer, it is a surprise that some other sections of departments are not (or so far have not been) accorded a degree of separate recognition in this way; a case in point is Emergency Management Australia, now part of a National Security and Criminal Justice Group within the Attorney-General's Department.

Some uncertainties of identification and classification can be attributed simply to the transitional nature of parts of the NDPB arena. Thus the Australian Climate Change Regulatory Authority was set up in anticipation of the passing of the climate change legislation, but in the event the government's plans stalled in the Senate and there was embarrassment in dealing with the staff already appointed. Again, the creation of an Australian National Preventative Health Agency, to be a commonwealth statutory agency but with close links to the intergovernmental Health Ministers' Conference, was proposed in legislation introduced in 2008 (Boxhall and Scully 2009), but that too was blocked in the Senate. The proposed Australian Business Investment Partnership Limited- the so-called Ruddbank - suffered the same fate: the government was to have had

9 Another very useful DoFD document brings together the FMA Act and the body of regulations under that Act. Among other things, these regulations are used to establish the 'prescribed agencies'. See DoFD (2009a). 
a 50 per cent stake and the 'big four' banks 12.5 per cent each in a mixedownership company intended to be manager of a fund to help commercial property companies struggling to refinance their loans in the global financial crisis (GFC) environment. And the High Court ruled in 2009 that the Australian Military Court set up in the late stages of the fourth Howard government was unconstitutional, forcing the Rudd government to plan a new military justice tribunal system that accorded with the Constitution. As a final example of the transitory character of some NDPB arrangements, the Defence Honours and Awards Tribunal was set up by ministerial direction and began operations in 2008; the intention was that it would be formally established by legislation 'at a later date' (DHAT 2008), but that did not happen in the period being reported on here.

Long-used practices in the use of the terms 'board' and 'commission' have undergone changes as the official codifying exercises have progressed. 'Board' was entrenched as the organisational centrepiece of one of Uhrig's two templates, whereas 'commission' is not now likely to have that status in the Commonwealth jurisdiction. DoFA/DoFD officers who advise on machinery-ofgovernment changes and have responsibility for producing these lists and flip charts now speak of authorities internal to departments as well as those external to departments, with some bearing the formal title 'commission' falling into the internal group. ${ }^{10}$

The term 'commission' does, however, continue to have another application. In longstanding practice in Australia and analogous countries, it has been used as a class name for bodies appointed to conduct inquiries into administrative and policy issues and problems, as in 'royal commission' (Prasser 2006). Their authority usually comes from letters patent issued by a head of state, not from a statute or company registration, and they are not usually considered to be part of the NDPB establishment. Notably in the period of the Rudd government, the National Health and Hospitals Reform Commission-its terms of reference set by the Council of Australian Governments (COAG) - operated with this sort of status (NHHRC 2008). An older regular NDPB, however, the Australian Law Reform Commission (ALRC 2010), has been giving consideration to ways of improving the use of such inquiry agents in the Commonwealth jurisdiction.

The opaqueness of the outer border of the public sector can be illustrated by two telling examples. The DoFD list includes Beyond Blue Limited, an intergovernmental (commonwealth, states, territories) company limited by guarantee and established in 2000 to 'provide a national focus...to increase the capacity of the broader Australian community to prevent depression and

10 My thanks to Marc Mowbray-d'Arbela and John Kalokerinos of the Legislative Review Branch of DoFA/ DoFD for many fruitful discussions exploring this and related machinery-of-government issues. 
respond effectively to it' (DoFD 2009a:424). The list does not include the Alcohol Education and Rehabilitation Foundation (AER), which describes itself as a 'notfor-profit company established by Federal Government legislation in 2001 with a mandate to "change the way we drink"' and as "the leading national voice for promoting research into and awareness of safe and responsible consumption of alcohol and prevention of licit substance abuse' (AER 2010). ${ }^{11}$ Although this AER is not in the DoFD list, another one is! This is the also-intergovernmental (and statutory) Australian Energy Regulator (DoFD 2009a:593)-demonstrating once more the ubiquity of the non-departmental 'fringe' and the classificatory difficulties it creates. ${ }^{12}$

The Parliament's Joint Committee on Public Accounts and Audit has used an entirely different sort of classification in its consideration of the impact of the efficiency dividend first imposed in 1987-88 and increased in incidence by the Rudd government in 2008-09. In this matter, governments have drawn no distinction between departments and NDPBs, though because the system applies only to funding that comes from parliamentary appropriations many NDPBs, especially the more commercial ones now operating under the CAC Act, have not been much affected. In its own deliberations, the committee has been particularly concerned about the impact of the dividend on 'small agencies' and it has used the term 'non-executive agencies' to apply to all agencies specifically established to be independent of the executive government - a meaning that has little or no relationship to 'executive agencies' as used in the Public Service and FMA Acts and in the DoFD lists. For the committee, the groups mainly affected-and mostly suffering badly because of the effects of the efficiency dividend system - are oversight agencies (for example, the Audit Office and the Ombudsman), cultural agencies (the National Museum, National Gallery, National Library - all statutory-authority administered), the courts and scientific agencies (JCPAA 2008).

In the very early days of the Rudd government, legislation to amend the CACAct that had been prepared in the late Howard period was introduced by incoming Finance Minister, Lindsay Tanner. The CAC Act was now amplified by bringing its requirements relating to reporting by and accountability and transparency of commonwealth companies into line with changed requirements for all companies under the general Corporations Act; by introducing a new class of 'general policy

\footnotetext{
11 These bodies are examples of what I identified as 'sideline' public sector companies, in contrast with the 'frontline' companies operating government business enterprises or GBEs (in Wettenhall 2003:32-6). One described itself as 'a private non-profit company established by the government'. The chief executive of another asked seriously: 'Are we public or are we private?'

12 For another example of this sort of classification uncertainty, see Chapter 12 of this volume for the account by Will Sanders and Janet Hunt of the creation of a 'new national Indigenous representative body' (a successor to the Aboriginal and Torres Strait Islander Commission) as a company limited by guarantee rather than a statutory authority, and said to be 'supported, but not quite so directly created, by the Commonwealth Parliament and government'.
} 
orders' covering instructions applying to public sector bodies generally; and by amending the definition of 'commonwealth company' to exclude subsidiaries of either existing companies or existing statutory authorities (Authorities and Companies Amendment Act [Cth] 20/2008; Tanner 2008:199-200). Similarly, there was an early adjustment to the FMA Act relating to agency transaction procedures, requiring agencies to establish audit committees and introducing provisions to cover circumstances in which agencies cease to exist (Financial Framework Legislation Amendment Act [Cth] 90/2008).

Emphasising this chapter's theme of continuity and change operating together, a Financial Framework Legislation Amendment Bill that had been long in preparation was introduced into the Parliament near the very end of the Rudd government. It would change some of the processes involved in the CAC and FMA systems and also vary the status of more NDPBs within those systems (notably the Australian Institute of Criminology, the Criminology Research Council, the Australian Law Reform Commission and the National Transport Commission). As these were not issues that divided the political parties, it could be assumed that this bill would eventually become law irrespective of the outcome of the August 2010 election.

There would be more to come. A 'tidying-up operation' headed by the machineryof-government team in DoFD had been under way for much of the Rudd period and was unlikely to be much affected by the outcome of the election. Planning was already under way for further changes, such as the merging of Centrelink and Medicare and the closure of more small government-owned companies.

\section{Waning of the Uhrig influence?}

The fourth Howard government had followed the Uhrig recommendations broadly (Wettenhall 2008:34-8), resulting in the closure of some NDPBs, the abolition of the boards of others so that their managements stood much closer to ministers and their departmental chiefs, and a general enhancement of ministerial authority over the whole NDPB arena. After the change of government, we heard little about the Uhrig agenda; one explanation was that mostly all that could be done had already been done; and of course it had conservative political associations. DoFA's (now DoFD's) governance arrangements document had Uhrig connections, however, and that was readily embraced by the Rudd ministers, so no radical process changes were to be expected.

The DoFD list (2009a:vii-viii) indicated a fairly significant movement away from the CAC arrangements (bodies with separate financial governance systems) to FMA arrangements, but that covered much of the fourth Howard period as well as the earlier part of the Rudd period so that it did not tell us much 
about differences in the styles of the two governments. That would need to be ascertained from a closer study of the creations and categorisations of the Rudd period.

Notwithstanding its deficiencies (Gourley 2009:19; Wettenhall 2005a:46), the Uhrig report was swimming with the tide. Uhrig surveyed and reported at a time when the great excitement with NPM doctrines such as devolution was being overtaken by the new search for whole-of-government solutions to administrative problems, motivated in part by the heightened national security situation and in part by growing awareness that those NPM doctrines had been taken to excess (on which see Chapter 3 of this volume). Paraphrasing The Canberra Times' editor-at-large, Jack Waterford (2009), devolution was out and central control was back in. In this climate, it was always likely that forces lined up against granting significant autonomy to administrative agencies would win over those in favour of greater autonomy.

There was no driving force in the NDPB arena in the period of the Rudd government to match the Howard-backed Uhrig in the previous period. The Finance Minister, Lindsay Tanner, whose department was producing these lists and flip charts, was, however, clearly influential. Tanner was active in many areas of public sector change and reform (see Chapter 3 of this volume). On NDPBs, he expounded on his developing views in some major speeches in late 2009, one of which involved the formal launch of the 2009 list at a conference of the Australian Institute of Company Directors in Canberra. The list was, he asserted, an important aid to improving the transparency of the Commonwealth government and its preparation had forced departments to examine their portfolio structures carefully and critically. The lesson was that they should try to accommodate new tasks within themselves before rushing to create new authorities; also that continuing review was necessary 'to bring some consistency' to the structure of agencies and their governance arrangements (Franklin 2009; Tanner 2009a; see also Hawthorn 2009). The whole exercise, he said, had been important in establishing 'a solid understanding of the current landscape of government' (Tanner 2009a:2).

Consistency is an important principle, but it might not count for much where there are strong arguments for special arrangements in particular cases. Thus, going somewhat against the general trend, Tanner advocated movement of the Future Fund from the FMA Act to the CAC Act so that it would have a degree of autonomy from government and ministers similar to that enjoyed by the Reserve Bank. Tanner was on record also as favouring a review of the system of making appointments to the boards of public sector bodies, and was associated with the bold decision to appoint Peter Costello, long-term Treasurer in the vanquished Howard government, to the board of the Future Fund (Wright 2009). Developments relating to the Australian Broadcasting Corporation $(\mathrm{ABC})$ and 
the Special Broadcasting Service (SBS) furthered this process; the government acted in 2008 to set up a merit-based system for appointments to the boards of these two authorities for which political impartiality was considered especially important. An independent nomination panel was to consider all applications for board positions against a core set of selection criteria and provide the minister with short lists of recommended candidates. If the minister wanted to go outside those short lists, he needed the Prime Minister's specific agreement, with a statement of reasons to be tabled in Parliament and, in the case of a chair position, the Leader of the Opposition had to be consulted (DBCDE 2010). This can be seen as a major step in reinforcing notions of autonomy and nonpartisanship that are so often associated with bodies in the non-departmental public sector. Whether it will become a model for application beyond the ABC and the SBS remains to be seen.

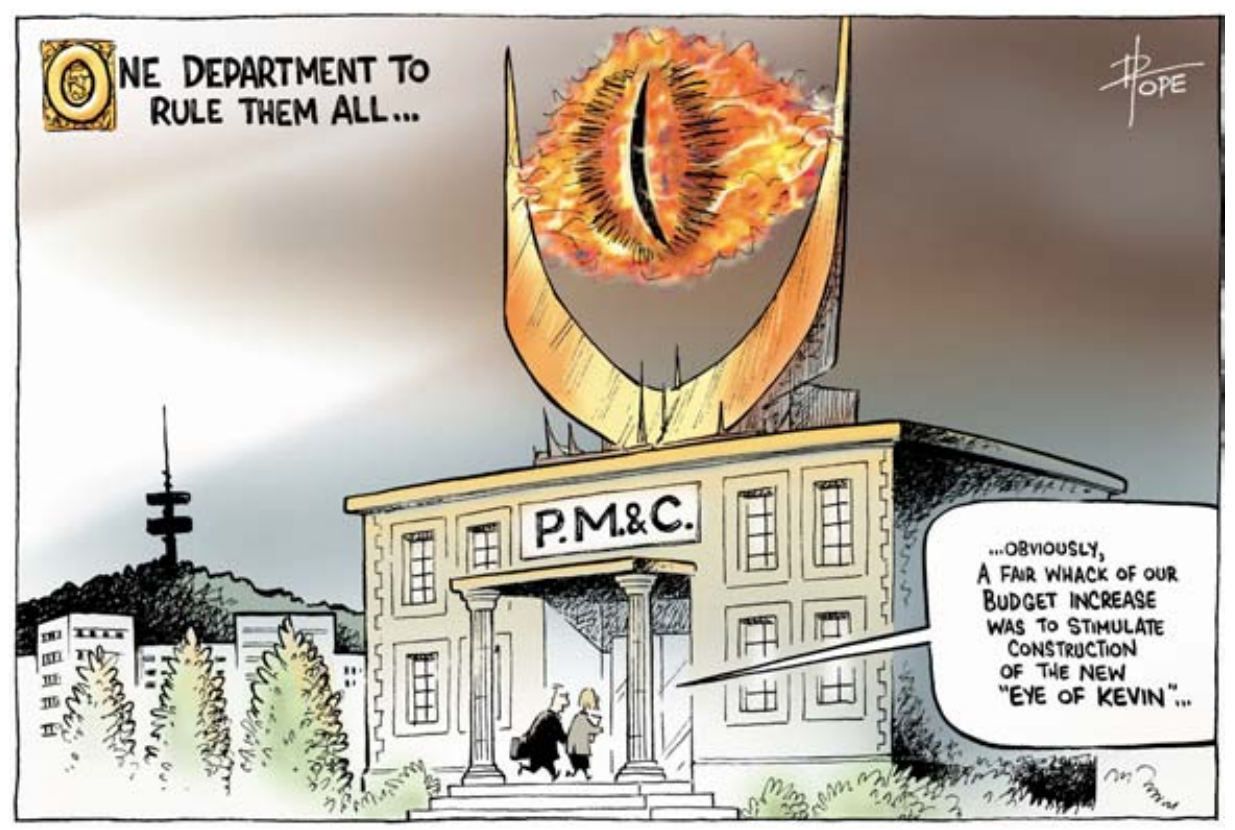

Source: David Pope, The Public Sector Informant, June 2009

\section{Privatisation, sovereign wealth funds, Chinese influences and the effects of the GFC}

Mention of the Future Fund furnishes a reminder that the idea of privatisationnow mostly off the Australian political radar - still has some traction, even if it is in part delusional. We have been encouraged to believe that Telstra is now fully privatised, but the fact is that residual government shareholdings after the third-tranche sale (worth about $\$ 9$ billion in late-2009 prices) were lodged 
in the very clearly publicly owned Future Fund, not sold to private buyers. The Future Fund is now firmly recognised as Australia's 'sovereign wealth fund', so it joins a variety of international publicly owned investment funds operating around the world and now grouped for study under this new class name. ${ }^{13}$ Privatisation proposals still emerge as fundraising schemes in the Australian states, but the only significant commonwealth manifestation occurred late in the period of the Rudd government as the Liberal-National Party opposition renewed calls for the sale of the government-owned health insurer confusingly known as Medibank Private.

Perhaps surprisingly, Chinese influences have been important. At a time when the output of Australia's mineral industry is so keenly sought by industrialising China, that country offers a reminder of the continuing great significance of state-owned enterprises in the world. Again and again, we have seen that Chinese state-owned enterprises such as the Aluminium Corporation of China (or Chinalco) are seeking to buy into private Australian mining firms. Clearance for such deals is required from the Australian Foreign Investment Review Board (FIRB; not a statutory body), and some such bids have been successful. Concern is not infrequently expressed, however, that the Chinese state-owned enterprises involved are really agents of the Chinese state, so their introduction into Australia gives the Chinese government great advantage in its dealings with the Australian government and Australian private firms. Assurances have been sought that these firms are free to operate in the market in their own best interests, but those assurances have not been forthcoming with any clarity (for example, AAP 2009; Garnaut 2009; Kroeber 2009). Further, it seems that, on the Chinese side, proceedings seen in the West as part of normal commercial negotiations can be regarded as encroaching on state national security secrets and leading to draconian punitive action ( $\mathrm{O}^{\prime}$ Malley and La Canna 2009). For those following these matters, the issue of relationships between governments and the NDPBs inhabiting the relevant public sectors is thus dramatically revived in Australia, having been imported from a foreign source.

The GFC of 2007-09 had major effects on the administrative systems of many countries as governments faced the need to redesign their systems for regulating financial institutions, acquired major shareholdings in failing banks and car manufacturers and actually brought some of those institutions totally into their public sectors; so, around the world as the GFC worked itself out, there were major impacts on the establishment of NDPBs. In Australia, however, the regulatory system based on NDPBs such as the Reserve Bank and the Australian Prudential Regulation Authority appeared to have been working well, with the Commonwealth government's $\$ 42$ billion stimulus package operating

13 The term 'sovereign wealth fund' was first used in an article in a 2005 issue of the Central Banking Journal (see Rozanov 2005; Truman 2009). 
mainly through direct payments to individuals, firms and state and territory governments and, where necessary, a mass of contracting-out arrangements. The whole GFC experience certainly aroused interest in NDPB-related issues such as the matter of applying lessons from past experience with mixed enterprises to aid policy makers in dealing with the new world crop of such enterprises, ${ }^{14}$ but in the event Australia escaped fairly lightly and the GFC did not of itself produce a need for major reconstruction in the NDPB arena.

\section{New creations, reorganisations and abolitions}

At the close of the fourth Howard government, there were 90 CAC bodies (including 64 statutory bodies and 26 companies) and 77 bodies (other than departments) listed under the FMA Act, making a total of 167 in these two major groups of commonwealth NDPBs (Wettenhall 2008:54, based on DoFA lists and flip charts). As hinted at above, there would also be several others not prescribed for either CAC or FMA treatment, some of them gathered around that rather indistinct border between the departmental part and the nondepartmental part of the Commonwealth public sector, and yet more inhabiting that even more indistinct 'no-man's-land' at the outer edge of the public sector.

The Governor-General's speech opening the new Parliament in February 2008 gave some hints of relevant measures to come when it indicated that the Rudd government was giving high priority to strengthening the nation's long-term economic prospects by inter alia introducing 'a plan of action on skills and infrastructure'; that it would be introducing an entirely new 'workplace relations system'; and that 'a Freedom of Information Commissioner [would] be appointed to take overall responsibility for access to government information and [to] improve review processes' (Jeffery 2008:2, 5, 10). Other NDPB developments had been anticipated in several policy documents issued in the lead-up to the late-2007 election - for example, the 'New Directions for the Arts' document referred to by the Minister for the Environment, Water, Heritage and the Arts in introducing legislation to reorganise government support for the film industry (Garratt 2008:832). That was one of many statutes affecting the NDPB arena that came quickly after the opening.

Changes in the Rudd period involved the creation of some new NDPBs with allocations to one or other of the CAC and FMA categories, sometimes resulting from conversions of others; the abolition of some NDPBs; and several shifts between the two categories. In many cases, the change process has been uncontroversial, unlikely to attract much public attention and not much

14 See discussion in Wettenhall (2010). 
affecting the performance of functions even where accounting arrangements have changed significantly. In other cases, however-for example, in the restructuring of industry regulatory and support arrangements - there has been substantial change to working systems, sometimes accompanied by protracted political debate reflecting deep divisions between government and opposition parties in the legislature.

The tables assembled in Appendix 4.3 seek to identify the new creations and conversions, status shifts and abolitions in summary form. The next section notes some of the major features of this change process, so supplements the data in these tables. The record is drawn primarily from data assembled in the statute book and parliamentary debates over the period of the Rudd government, with space considerations preventing comprehensive referencing of all sources used. As far as possible, I have attempted to concert my record with that in the DoFD list; however, a perfect correlation is not possible because that list covers a different (though overlapping) reporting period. Also, building on a point made earlier, the outer border of the public sector is so opaque that a major research project would be necessary before there could be certainty that all relevant changes in that area had been identified.

\section{Features of the change process}

The first few weeks of the new Parliament saw speedy passage of legislation creating several of these new authorities, and several main features of the change process were already apparent. There was continuity with the earlier Howard period to the extent that quite a few of the changes were being planned within the bureaucracy - in part as a legacy of the Uhrig review-before the change of government.

Several features impacting on organisational or titular arrangements need immediately to be noticed. First, some of the changes affected clusters of NDPBs, not just single ones. In industrial relations, water management and film industry support particularly, new agencies were created, old ones displaced and some functions shifted between agencies, so that several were affected in a single adjustment. Second, drafting habits affected patterns of nomenclature, in that the tendency to eliminate class words such as 'board', 'commission' and 'authority' from formal titles gathered pace - witness Fair Work Australia, Safe Work Australia, Skills Australia, Infrastructure Australia, Screen Australia, National Film and Sound Archive Australia, Wheat Exports Australia and Health Workforce Australia.

The trend towards the reduction or elimination of boards and the concentration of authority in the hands of chief executives continued, although there was much variation within that general pattern. In the official thinking, boards now 
seemed to be clearly differentiated from commissions, about which there was some ambiguity. In some cases (for example, Skills Australia, Infrastructure Australia, Wheat Exports Australia), the agency comprised a chair and members (along with supporting staff) with no statutory reference to either board or commission. In the rearranged Fisheries Management Authority, the board was replaced by a commission and $\mathrm{CEO}$, the minister having discretion to appoint the same person as both chair and CEO. In the rearranged Australian Sports Anti-Doping Authority, the CEO is now declared unambiguously to be the agency head. This trend is associated with the increasing currency of 'statutory agency' - a convenient title for agencies staffed under the Public Service Act introduced in the revision of that Act in 1999. Linking two of these features, the Minister for Infrastructure, Transport, Regional Development and Local Government, Anthony Albanese, described the rearranged Australian Transport Safety Bureau as 'a separate statutory agency... [with] a commission structure' (Albanese 2009:1110). All this is consistent with Uhrig's 'executive management template' in which CEOs are accountable directly to ministers, and of course consistent also with both the movement from CAC to FMA status and the general thrust towards whole-of-government arrangements.

The changes to the Civil Aviation Safety Authority (CASA) buck the general trend, reinstating a board previously disposed of after continuing clashes between board members and the minister (see Wettenhall 2000:83-4, 2005d:82). After an inquiry, a senate committee reported that CASA lacked significant policy direction, that layers of management had increased since removal of the old board and that the CEO was now forced to wear two hats-both policy and executive direction; it concurred with the majority stakeholder view that restoration of the board would enhance CASA's governance and accountability (SSCRRAT 2008:32-6, 48). Perhaps Uhrig should have undertaken a few actual case studies of this sort!

Boards generally continue in the agencies remaining under the CAC Act and especially in those of an intergovernmental character. There has been a long history of intergovernmental NDPBs serving the Australian federation-a notable early example being the River Murray Commission established by an agreement between the Commonwealth and three state governments in 1914, ratified by legislation passed in each of the four legislatures and with each government then appointing a commissioner. Over the past few decades, other such bodies have appeared, usually at the instigation of one or other of the 'ministerial councils' that now link commonwealth, state and territory ministers in related portfolios, with the related bodies directed by and reporting to those councils. It has increasingly been left to the Commonwealth to enact creating legislation as necessary, building in the rights of all involved governments to participate in board appointments, to issue directions and receive reports. 
Though the formula has differed from case to case, in the period under review, that has happened with the Murray-Darling Basin Authority, the Australian Curriculum Assessment and Reporting Authority, Safe Work Australia, Health Workforce Australia and Infrastructure Australia.

COAG has been involved in several of these creations and itself spawned another NDPB - the non-statutory COAG Reform Council-in the late Howard period. With the task of monitoring, assessing and reporting on the performance of all Australian governments, the council reports to the Prime Minister as chair of COAG and has a secretariat in the Department of the Prime Minister and Cabinet (Griffith 2009). Together with the tendency to use the Commonwealth Parliament as the creating instrument for these intergovernmental agencies, this arrangement must be seen as part of the increasing dominance of the Commonwealth within the federation.

Impulses for change have come from virtually all points of the political compass. As indicated elsewhere in this book, industrial relations featured as one of the battlegrounds between the political parties in the lead-up to the 2007 election, and it was inevitable that the array of agencies operating in that area would undergo major change after the governmental transition. It was a recommendation of a consultant who reported in 2007 on the relationship between CASA and the Australian Transport Safety Bureau that led to clarification of the latter's status as an 'independent' statutory authority (Albanese 2009:1110). A report from another NDPB, the Productivity Commission, was a significant influence on the decision to establish Health Workforce Australia (Productivity Commission 2005; Roxon 2009:3616). Of course, not all such proposals are accepted; the Independent (but government-appointed) Sports Panel reporting in 2009 wanted the Australian Institute of Sport separated from the Australian Sports Commission, but that recommendation was rejected (Crawford 2009; Ellis 2010).

Other impulses were generated by community influences mostly away from the main interests of the political parties - some attracting sufficient support to be translated into legislative and administration action. Thus an alliance comprising mostly food industry leaders, health professionals and the immediate past governor-general spearheaded the process that led to creation of the National Organ and Tissue Donation and Transplantation Authority (ABC 2010). ${ }^{15}$ Not so successful was the advocacy of a Stolen Generations Reparations Tribunal by a group consisting of the Public Interest Advocacy Centre and the Australian Human Rights Centre, which pushed through a senate inquiry and a private member's bill in the Senate but with no governmental or strong parliamentary inclination to be supportive (Stewert 2008:5520).

15 This creation would also have had the strong support of a prime minister who had himself been the recipient of an organ transplant (The Canberra Times 2010). 
Other proposals circulating but not consummated included those for a public sector regulator to review breaches of the financial regulations by government departments and agencies, a parliamentary standards commissioner to scrutinise use of electoral allowances by MPs, a children's commissioner to be associated with the Human Rights Commission, an Australian space agency and (from the Leader of the Opposition, Tony Abbott) a commission to advise on sustainable population growth levels (Cronin 2010).

A safe prediction is that there will always be a large outer public sector. It serves many community interests - governmental and other. So the big question is not so much how many constituent units that assemble within it, but how they relate to central government and the ministers that direct it. The issue of the relationship between agency and supervising minister has received much attention in the NDPB literature over the years, and of course a leading effect of Uhrig was that commonwealth ministers were generally strengthened in this relationship. There has been a gradual attrition of agency autonomy over the years since the first Australian statutory corporations were protected in so many ways from ministerial intervention in operational matters.

Through most of the twentieth century, it could be said that Labor governments generally favoured more intrusive controls than non-Labor ones. It would, however, be difficult to draw that distinction today. Whatever policy, partisan and personality issues separate the main political parties, Labor and non-Labor have shared not only in the attractions of managerialism that came with the NPM movement but also in the subsequent push for whole-of-government solutions generated in large part by the security situation. In this they are like peas in a pod: in this part of the NDPB experience, there has been substantial continuity over the transition from Howard to Rudd. It would be interesting to study the NDPB situation in the states to see whether they also reflect this trend.

\section{Agencies in action: a massive contribution to good governance}

A mid-2010 DoFD flip chart recognises 91 bodies under the CAC Act and 81 (other than departments) under the FMA Act (DoFD 2010); also, as noted above, there will be some other NDPBs not (or not yet) gathered in these groups. All the constituents of this establishment of 170-plus agencies go about their allotted tasks mostly quietly and unostentatiously, making a huge collective contribution to society, the economy and the processes of good governance generally.

At any particular time, of course, it is likely that a small number will be attracting much public and media attention. This could be because the political parties are 
involved in contests about their missions or because they have been creating waves themselves through their own occasionally dysfunctional actions. But it could also reflect the fact that, for some, the attraction of public notice is virtually unavoidable in the light of the missions allotted to them. As Peres (1967:362) pointed out many years ago, NDPBs range along a spectrum running from tight definitions of mission that allow very limited policy discretions to much looser definitions that allow competing conceptions of activity or confer judgmental responsibilities - and those in the latter group can be said to have a 'high controversy quotient'. Where NDPBs have been particularly newsworthy at some time during the period of the Rudd government, it could have been for any of these reasons.

A final indication of the importance to the society and the economy of the population of commonwealth NDPBs, and of the diversity of activities of members of that population, comes from a random selection of a few that have attracted much public and media attention - a lot of it positive but also some negative - in the period under review. It is likely that the Reserve Bank takes pride of place in this group, mostly because of its ongoing role in determining basic interest rates. Others to attract much attention have included Centrelink, CSIRO, the Australian Federal Police, the National Capital Authority, the Murray-Darling Basin Authority, and Fair Work Australia and its forebears and associates in implementing industrial relations policies.

\section{Concluding comment: need for a 'college' of NDPBs?}

Machinery-of-government systems are cyclical in nature, moving backwards and forwards between centralising and decentralising phases (Aulich and Wettenhall 2009:103-9), and we can expect the outer NDPB sector to expand and enjoy greater autonomy in the decentralising periods. The Australian Commonwealth system is no exception and the current focus on the whole of government can be seen as a centralising force. On the evidence, it has not led to any significant decrease in the number of NDPBs, but there has been a strong tendency to reduce the autonomy of the individual units. There are, of course, usually aberrant cases (such as, in this period, the Reserve Bank, the Future Fund and, reversing an older aberrant decision, CASA).

There is always a question of balance. Governments need to have sufficient authority to ensure overall harmony in public sector operations. But that should not deprive the units of room to discharge their functions with a reasonable degree of autonomy and effectiveness. Again, on the evidence, the Commonwealth's NDPB sector is currently not working badly, though there are black spots. It is, 
however, under threat from those who want to push the whole-of-government argument strongly. There seems to be little awareness that there is a countercase to be made. Uhrig is still the exemplar here, always concerned to enhance ministerial authority and prepared to draw conclusions about the whole sector notwithstanding lack of effort to communicate with most of it. Others who give scant attention to the outer public sectors entrench this approach to its general detriment.

As agents as various as the Coombs Royal Commission, Uhrig and Tanner have pointed out, we need to be sure there is a strong case for establishing an NDPB before removing a function from direct (and often quite flexible) ministerial/ departmental administration. When we do, however, we need to be aware that we have opted for a different pattern of administration. The evidence suggests that, away from the more obviously distinctive group of government business enterprises, that awareness is lacking.

In the long history of NDPB arrangements, there have been occasions wheneither out of consciousness of threat to the group or from a sense of good order - all or most of the non-departmental units in a particular jurisdiction have come together in what might be seen as a 'college' to explore problems they have in common, develop some common stances and gain attention for their collective effort to serve society, the economy and the system of governance that would not otherwise come to them. In several countries, the public (state, government-business) enterprises have done this (Wettenhall and O Nuallain 1987); in the Australian Commonwealth, it happened during the Coombs Royal Commission's investigation (Wettenhall 1981:16-18) and again when there was much dissention over the efforts of the Hawke government to enunciate a general agency policy (Painter 1986). Perhaps this should be happening now, to balance the effects of Uhrig, the Moran inquiry and all the other centralising forces that are at work.

Roger Wettenhall is Emeritus Professor in Public Administration at the University of Canberra and a Visiting Professor at the university's ANZSOG Institute for Governance. 
The Rudd Government

\section{References}

Albanese, A. 2009. Second Reading Speech on Transport Safety Investigation Amendment Bill, House of Representatives, Debates, 12 February.

Alcohol Education and Rehabilitation Foundation (AER) 2010. 'Call for applications for position of Chief Executive Officer', The Canberra Times, 17 April.

Aulich, C. and Wettenhall, R. 2009. 'The public sector's use of agencies: a dynamic rather than static scene', Public Organization Review, vol. 9, no. 2, pp. 101-18.

Australian Associated Press (AAP) 2009. 'Review board grills Chinalco over juicy Rio Tinto stake', The Canberra Times, 3 March.

Australian Broadcasting Corporation (ABC) 2010. 'Organ donor transplant problems', Transcript, Health Report, ABC Radio National, 3 May.

Australian Law Reform Commission (ALRC) 2010. Making inquiries: a new statutory framework, ALRC Report 111, Australian Law Reform Commission, Sydney.

Boxall, A.-M. and Scully, S. 2009. Australian National Preventative Health Agency Bill 2009, Bills Digest, no. 34, Parliamentary Library, Canberra.

Coombs, H. C. 1976a. Report, AGPS, Canberra.

Coombs, H. C. 1976b. Royal Commission on Australian Government Administration: Appendix volume one, AGPS, Canberra, pp. 312-64.

Crawford, D. 2009. The Future of Sport in Australia, Department of Health and Ageing, Commonwealth of Australia, Canberra.

Cronin, D. 2010. 'Coalition reveals targets for cuts', The Canberra Times, 20 May.

Department of Broadband, Communications and the Digital Economy (DBCDE) 2010. ABC and SBS Board Appointments, Department of Broadband, Communications and the Digital Economy, Commonwealth of Australia, Canberra, <www.dbcde.gov.au/television/abc_and_sbs_board_ appointments $>$

Defence Honours and Awards Tribunal (DHAT) 2008. Initiating Directive, Defence Honours and Awards Tribunal, Canberra, <www.defence-honourstribunal.gov.au/initiating-directive $>$ 
4. Continuity and change in the outer public sector

Department of Finance and Administration (DoFA) 2005. Governance Arrangements for Australian Government Bodies, Department of Finance and Administration, Commonwealth of Australia, Canberra.

Department of Finance and Deregulation (DoFD) 2009a. List of Australian Government Bodies and Governance Relationships, (Third edition), Department of Finance and Deregulation, Commonwealth of Australia, Canberra.

Department of Finance and Deregulation (DoFD) 2009b. Financial Management and Accountability Legislation, October 2009, Department of Finance and Deregulation, Commonwealth of Australia, Canberra.

Department of Finance and Deregulation (DoFD) 2010. CAC Act and FMA Act charts, 15 March, Department of Finance and Deregulation, Commonwealth of Australia, Canberra.

Department of Prime Minister and Cabinet (PM\&C) 2007. Administrative Arrangements Order, 3 December, Department of Prime Minister and Cabinet, Commonwealth of Australia, Canberra.

Ellis, K. 2009. House of Representatives, Debates, 16 September, p. 9713.

Ellis, K. 2010. Australian Sport: The pathway to success, Commonwealth of Australia, Canberra, <www.health.gov.au/internet/main/publishing.nsf/ Content/pathway-to-success $>$

Franklin, M. 2009. 'Tanner cracks down on public sector agencies', The Australian, 15 October.

Garnaut, J. 2009. 'The dragon set to devour Rio [Tinto]', Sydney Morning Herald, 12 February.

Garratt, P. 2008. Second Reading Speech: National Film and Sound Archive Bill, House of Representatives, Debates, 20 February, pp. 831-4.

Gourley, P. 2009. 'The Moran review: the good, the bad and the ludicrous', The Public Sector Informant, November.

Griffith, G. 2009. Managerial Federalism: COAG and the states, Parliament of New South Wales, Sydney.

Hawthorne, M. 2009. 'Comrade Tanner', The Age, 15 October.

Ja, C. 2010, 'Economist "harassed" by CSIRO over paper', The Canberra Times, 11 February. 
Joint Committee of Public Accounts and Audit (JCPAA) 2008. The efficiency dividend and small agencies: size does matter, Report 413, Parliament of the Commonwealth of Australia, Canberra.

Jeffery, M. 2008. Governor-General's speech, Senate, Debates, 12 February, pp. 3-10.

Kroeber, A. 2009. Extended interview with Arthur Kroeber, Managing Director of Dragonomics, Beijing, ABC Radio National, 10 November.

Ludwig, J. 2010. APS recognised in United Nations 2010 Public Service Awards, Media release, 7 June, Parliament House, Canberra.

Mannheim, M. 2010. 'Aust Post rules out compromise', The Canberra Times, 8 February.

Moran, T. 2009. Reform of Australian Government Administration: Building the world's best public service, Advisory Group on Reform of Australian Government Administration, Department of the Prime Minister and Cabinet, Commonwealth of Australia, Canberra.

Moran, T. 2010. Ahead of the Game: Blueprint for the reform of Australian government administration, Department of the Prime Minister and Cabinet, Commonwealth of Australia, Canberra.

National Health and Hospitals Reform Commission (NHHRC) 2008. National Health and Hospitals Reform Commission, Woden, ACT, <www.healtrh.gov. au/internet/main/publishing.nsf/Content/nhrc-1>

O'Malley, S. and La Canna, X. 2009. 'China's view of secrets under fire', The Canberra Times, 11 July.

Painter, M. (ed.) 1986. 'Public management forum: guidelines for government business enterprises', Australian Journal of Public Administration, vol. 45, no. 4, pp. 281-343.

Productivity Commission 2005. Report on Australia's Health Workforce, Productivity Commission, Melbourne.

Peres, L. 1967. 'The resurrection of autonomy: organization theory and the statutory corporation', Public Administration [Sydney], vol. 17, no. 4, pp. 360-70.

Podger, A. 2009. The Role of Departmental Secretaries: Personal reflections on the breadth of responsibilities today, ANU E Press, Canberra. 
Prasser, S. 2006. Royal Commissions and Public Inquiries in Australia, LexisNexis Butterworth, Sydney.

Roxon, N. 2009. Second Reading Speech: Health Work Force Australia Act, House of Representatives, Debates, 13 May.

Rozanov, A. 2005. 'Who holds the wealth of nations?', Central Banking Journal, vol. 15 , no. 4 .

Rudd, K. 2010. Ministerial changes, Media release, 26 February, Parliament House, Canberra.

Senate Standing Committee on Rural and Regional Affairs and Transport (SSCRRAT) 2008. Report on Administration of Civil Aviation Safety Authority and Related Matters, Parliament of the Commonwealth of Australia, Canberra.

Stewert, R. 2008. Second Reading Speech: Stolen Generations Reparations Tribunal Bill 2008, Senate, Debates, 24 September.

Tanner, L. 2008. Second Reading Speech: Commonwealth Authorities and Companies Amendment Bill, House of Representatives, Debates, 13 February, pp. 199-200.

Tanner, L. 2009a. Speech to Australian Institute of Company Directors Public Sector Governance Conference, Canberra, 14 October.

Tanner, L. 2009b. The Future Fund: delivering for Australia, Address to National Press Club of Australia, Canberra, 25 November.

The Canberra Times 2008. 'Govt sets investing principles', The Canberra Times, 18 February.

The Canberra Times 2010. 'Rudd says his problems "hardly significant"', The Canberra Times, 16 August.

Truman, E. M. 2009. Sovereign wealth funds: the need for greater transparency and accountability, Policy Brief 07-8, Peterson Institute for International Economics, Washington, DC.

Uhrig, J. 2003. Review of the Corporate Governance of Statutory Authorities and Office Holders, Department of Finance and Administration, Commonwealth of Australia, Canberra.

Viviani, N. and Wilenski, P. 1978. The Australian Development Assistance Agency: A post mortem report, RIPA, Brisbane.

Walsh, P. 1986. Statutory Authorities and Government Business Enterprises, AGPS, Canberra. 
Waterford, J. 2009. 'On a west wing and a prayer', The Canberra Times, 16 May.

Wettenhall, R. 1987a. 'Federal Labor and the statutory corporation under Matthew Charlton', in Public Enterprise and National Development: Selected essays, Royal Australian Institute of Public Administration (ACT Division), Canberra.

Wettenhall, R. 1987b. 'Statutory authorities and government business enterprises: some observations on recent policy papers', in Public Enterprise and National Development: Selected essays, Royal Australian Institute of Public Administration (ACT Division), Canberra.

Wettenhall, R. 2003. "Kaleidoscope", or "now we see them, now we don't!": Commonwealth public sector involvement in company formation', Canberra Bulletin of Public Administration, no. 110, pp. 29-44.

Wettenhall, R. 2005a. 'Parliamentary oversight of statutory authorities: a postUhrig perspective', Australasian Parliamentary Review, vol. 20, no. 2, pp. 39-63.

Wettenhall, R. 2005b. 'Statutory authorities, the Uhrig report, and the trouble with internal inquiries', Public Administration Today, no. 2, pp. 62-76.

Wettenhall, R. 2007. 'Non-departmental bodies under the Howard governments', Australian Journal of Public Administration, vol. 66, no. 1, pp. 62-82.

Wettenhall, R. 2008. 'Non-departmental public bodies as a focus for machineryof-government change', in C. Aulich and R. Wettenhall (eds), Howard's Fourth Government: Australian Commonwealth Administration 2004-2007, UNSW Press, Sydney, pp. 31-56.

Wettenhall, R. 2010. Submission to Advisory Group on Reform of Australian Government; 'Whole-of-Government' and Non-Departmental Public Bodies, Submission 0079, Department of the Prime Minister and Cabinet, Commonwealth of Australia, Canberra, <www.dpmc.gov.au/consultation/ aga_reform/submissions/cfm>

Wettenhall, R. (forthcoming). 'Mixed enterprise and the global financial crisis: relevance for the 21 st century of a 20th century institution', Asian Review of Public Administration, vol. 21, no. 1.

Wettenhall, R. and O Nuallain, C. (eds) 1987. Getting Together in Public Enterprise, IIAS, Brussels. 


\section{Appendix 4.1}

\section{Departments under the Rudd government*}

\section{Table A4.1.1 Ministerial (portfolio) departments}

\begin{tabular}{|c|c|}
\hline Final Howard arrangements & Rudd arrangements (3 December 2007) \\
\hline No change & Agriculture, Fisheries and Forestry \\
\hline No change & Attorney-General \\
\hline $\begin{array}{l}\text { Was Communications, Information } \\
\text { Technology and the Arts }\end{array}$ & $\begin{array}{l}\text { Broadband, Communications and the Digital } \\
\text { Economy }\end{array}$ \\
\hline No change & $\begin{array}{l}\text { Defence(with Veterans' Affairs as separate } \\
\text { outlier department) }\end{array}$ \\
\hline $\begin{array}{l}\text { Was: } \\
\text { 1) Education, Science and Training } \\
\text { 2) Employment and Workplace Relations }\end{array}$ & $\begin{array}{l}\text { Education, Employment and Workplace } \\
\text { Relations }\end{array}$ \\
\hline Was Environment and Water Resources & Environment, Water, Heritage and the Arts \\
\hline $\begin{array}{l}\text { Was Families, Community Services and } \\
\text { Indigenous Affairs }\end{array}$ & $\begin{array}{l}\text { Families, Housing, Community Services and } \\
\text { Indigenous Affairs }\end{array}$ \\
\hline $\begin{array}{l}\text { Was Finance and Administration (with } \\
\text { Human Services as separate outlier } \\
\text { department) }\end{array}$ & Finance and Deregulation \\
\hline No change & Foreign Affairs and Trade \\
\hline No change & Health and Ageing \\
\hline Was outlier of Finance and Administration & Human Services \\
\hline No change & Immigration and Citizenship \\
\hline $\begin{array}{l}\text { Was: } \\
\text { 1) Industry, Tourism and Resources } \\
\text { 2) Transport and Regional Services }\end{array}$ & $\begin{array}{l}\text { Infrastructure, Transport, Regional } \\
\text { Development and Local Government }\end{array}$ \\
\hline+ & Innovation, Industry, Science and Research \\
\hline Prime Minister and Cabinet & $\begin{array}{l}\text { Prime Minister and Cabinet (with Climate } \\
\text { Change^ }^{\wedge} \text { as a separate outlier department) }\end{array}$ \\
\hline+ & Resources, Energy and Tourism \\
\hline No change & Treasury \\
\hline
\end{tabular}

\section{Table A4.1.2 Parliamentary departments ${ }^{\#}$}

\begin{tabular}{|l|}
\hline Department of the House of Representatives \\
\hline Department of the Senate \\
\hline Department of Parliamentary Services \\
\hline
\end{tabular}

* Compiled from document showing the track-change variations made to the Administrative Arrangements Order of 21 September 2006 (Howard) to produce the Administrative Arrangements Order of 3 December 2007 (Rudd).

+ No corresponding department; instead, parts of other departments used to constitute the new one.

$\wedge$ Expanded to Climate Change and Energy Efficiency on 26 February 2010 (Rudd 2010). Note that the ministerial reshuffle of 6 June 2009 did not involve changes in the departmental arrangements. 
The Rudd Government

\section{Appendix 4.2}

\section{Examples of quasi-separate parts of departments recognised in the DoFD lists}

Prescribed agency (not executive agency or statutory body)

- Australian Agency for International Development (AusAID) within Department of Foreign Affairs and Trade

- Defence Materiel Organisation (DMO) within Department of Defence

- Geoscience Australia within Department of Resources, Energy and Tourism

- IP Australia within Department of Innovation, Industry, Science and Research

- Royal Australian Mint within Department of the Treasury

Business operation

- Australian Quarantine and Inspection Service (AQIS) within Department of Agriculture, Fisheries and Forestry

- Therapeutic Goods Administration (TGA) within Department of Health and Ageing

Function with separate branding

- Artbank within Department of Environment, Water, Heritage and the Arts

- Australian Antarctic Division within Department of Environment, Water, Heritage and the Arts

- Australian Bureau of Agricultural and Resource Economics (ABARE) within Department of Agriculture, Fisheries and Forestry

- Australian Government Information Management Office (AGIMO) within Department of Finance and Deregulation

- Defence Science and Technology Organisation (DSTO) within Department of Defence

- National Portrait Gallery within Department of Environment, Water, Heritage and the Arts 


\section{Appendix 4.3*}

\section{Table 4.3.1 Creations and conversions: statutory authorities}

\begin{tabular}{|c|c|c|}
\hline Name Under the CAC Act & Creating act & Comment \\
\hline Screen Australia & $12 / 2008$ & $\begin{array}{l}\text { Body corporate and statutory agency, } \\
\text { replacing Australian Film Commission, Film } \\
\text { Australia Ltd and Film Finance Corporation } \\
\text { Ltd }\end{array}$ \\
\hline $\begin{array}{l}\text { National Film and Sound } \\
\text { Archive }\end{array}$ & $14 / 2008$ & $\begin{array}{l}\text { Body corporate and statutory agency, } \\
\text { created out of part of Australian Film } \\
\text { Commission }\end{array}$ \\
\hline $\begin{array}{l}\text { Albury-Wodonga } \\
\text { Development Corporation }\end{array}$ & $90 / 2008$ & $\begin{array}{l}\text { A long-existing statutory corporation, } \\
\text { coming into CAC framework for first time }\end{array}$ \\
\hline $\begin{array}{l}\text { Australian Curriculum } \\
\text { Assessment and Reporting } \\
\text { Authority }\end{array}$ & $136 / 2008$ & $\begin{array}{l}\text { Body corporate, to develop national school } \\
\text { curriculum; may charge fees and recruits } \\
\text { own staff }\end{array}$ \\
\hline $\begin{array}{l}\text { Civil Aviation Safety } \\
\text { Authority }\end{array}$ & $19 / 2009$ & $\begin{array}{l}\text { Body corporate with board restored (it had } \\
\text { been removed in 1993) }\end{array}$ \\
\hline
\end{tabular}

\section{Name Under the FMA Act}

\begin{tabular}{|c|c|c|}
\hline $\begin{array}{l}\text { Australian Fisheries } \\
\text { Management Authority }\end{array}$ & $36 / 2008$ & $\begin{array}{l}\text { Moved from CAC Act to FMA Act; still } \\
\text { a body corporate and now a statutory } \\
\text { agency, with CEO replacing earlier } \\
\text { authority board; now supported by a } \\
\text { commission }\end{array}$ \\
\hline $\begin{array}{l}\text { Australian Accounting } \\
\text { Standards Board (AASB, } \\
\text { Office of) }\end{array}$ & $61 / 2008$ & $\begin{array}{l}\text { Moved from CAC Act to FMA Act; } \\
\text { no separate corporate identity; now a } \\
\text { statutory agency; acquired some functions } \\
\text { from Financial Reporting Council }\end{array}$ \\
\hline $\begin{array}{l}\text { Auditing and Assurance } \\
\text { Standards Board (AUASB, } \\
\text { Office of) }\end{array}$ & $61 / 2008$ & As for AASB \\
\hline $\begin{array}{l}\text { National Organ and Tissue } \\
\text { Donation and Transplantation } \\
\text { Authority }\end{array}$ & $122 / 2008$ & $\begin{array}{l}\text { Statutory agency constituted by a CEO } \\
\text { and staff, assisted by a statutory Advisory } \\
\text { Council }\end{array}$ \\
\hline $\begin{array}{l}\text { Murray-Darling Basin } \\
\text { Authority }\end{array}$ & $139 / 2008$ & $\begin{array}{l}\text { Body corporate and statutory agency, } \\
\text { representing a merger of earlier MDB } \\
\text { Commission and MDB Authority; } \\
\text { intergovernmental and reports to MDB } \\
\text { Ministerial Council. There are satellite } \\
\text { statutory bodies: Basin Officials } \\
\text { Committee, Basin Community Committee } \\
\text { and Commonwealth Environmental Water } \\
\text { Holder }\end{array}$ \\
\hline Safe Work Australia & $\begin{array}{l}175 / 2008 \text { and } \\
84 / 2009\end{array}$ & $\begin{array}{l}\text { A statutory agency replacing Australian } \\
\text { Safety and Compensation Council; } \\
\text { intergovernmental and reports to } \\
\text { Workplace Relations Ministerial Council }\end{array}$ \\
\hline $\begin{array}{l}\text { Australian Transport Safety } \\
\text { Bureau }\end{array}$ & $20 / 2009$ & $\begin{array}{l}\text { Formerly a marginal structure in transport } \\
\text { ministry, now clearly separate as a } \\
\text { statutory agency }\end{array}$ \\
\hline
\end{tabular}


The Rudd Government

\begin{tabular}{|c|c|c|}
\hline Fair Work Australia & $28 / 2009$ & $\begin{array}{l}\text { With a quasi-judicial bench and replacing } \\
\text { Australian Fair Pay Commission, Australian } \\
\text { Industrial Relations Commission, Australian } \\
\text { Industrial Registry and Workplace } \\
\text { Authority; general manager and staff } \\
\text { constitute a statutory agency }\end{array}$ \\
\hline $\begin{array}{l}\text { Fair Work Ombudsman } \\
\text { (Office of) }\end{array}$ & $28 / 2009$ & $\begin{array}{l}\text { A statutory agency replacing Workplace } \\
\text { Ombudsman }\end{array}$ \\
\hline $\begin{array}{l}\text { Australian Customs and } \\
\text { Border Protection Service }\end{array}$ & $33 / 2009$ & Formerly Australian Customs Service \\
\hline $\begin{array}{l}\text { Australian Sports Anti- } \\
\text { Doping Authority }\end{array}$ & $113 / 2009$ & $\begin{array}{l}\text { Moved from CAC Act to FMA Act; } \\
\text { a statutory agency with CEO now } \\
\text { unambiguously as agency head; board } \\
\text { replaced by subsidiary Advisory Group and } \\
\text { Rule Violation Panel^ }\end{array}$ \\
\hline $\begin{array}{l}\text { Australian Information } \\
\text { Commissioner (Office of) }\end{array}$ & $52 / 2010$ & $\begin{array}{l}\text { To begin November } 2010 \text { and to include } \\
\text { Commissioner for Information, Privacy } \\
\text { Commissioner (no longer a separate office) } \\
\text { and Freedom of Information Commissioner }\end{array}$ \\
\hline \multicolumn{3}{|l|}{$\begin{array}{l}\text { Advisory structures on the } \\
\text { margins of departments }\end{array}$} \\
\hline Infrastructure Australia & $17 / 2008$ & $\begin{array}{l}\text { With a statutory office of Infrastructure } \\
\text { Coordinator }\end{array}$ \\
\hline Skills Australia & $10 / 2008$ & \\
\hline $\begin{array}{l}\text { Education Investment Fund } \\
\text { Advisory Board }\end{array}$ & $154 / 2008$ & As part of GFC stimulus package \\
\hline $\begin{array}{l}\text { Health and Hospitals Fund } \\
\text { Advisory Board }\end{array}$ & $154 / 2008$ & As part of GFC stimulus package \\
\hline $\begin{array}{l}\text { Coordinator-General for } \\
\text { Remote Indigenous Services }\end{array}$ & $68 / 2009$ & $\begin{array}{l}\text { A statutory official with office to be } \\
\text { staffed within Department of Families, } \\
\text { Housing, Community Services and } \\
\text { Indigenous Affairs }\end{array}$ \\
\hline
\end{tabular}

* Details of company changes taken from DoFD (2009a:x-xiii).

^ Previous form described as a CAC-FMA 'hybrid' by Ellis (2009:9713).

\section{Table 4.3.2 Creations and conversion: executive agencies}


Table 4.3.3 Creations and conversions: government-owned companies (all under $C A C$ Act)

\begin{tabular}{|l|l|}
\hline $\begin{array}{l}\text { AAF Company (Army } \\
\text { Amenities Food Co.) }\end{array}$ & Created 1 July 2008 \\
\hline $\begin{array}{l}\text { Australian Learning and } \\
\text { Teaching Council Ltd }\end{array}$ & $\begin{array}{l}\text { Created 1 July 2009; previously Carrick Institute for } \\
\text { Learning and Teaching in Higher Education Ltd }\end{array}$ \\
\hline Australian Solar Institute Ltd & Created 10 August 2009 \\
\hline Australian Sports Foundation & $\begin{array}{l}\text { Created } 18 \text { February 1986; brought under CAC Act on 23 } \\
\text { July 2009 }\end{array}$ \\
\hline $\begin{array}{l}\text { National Breast and Ovarian } \\
\text { Cancer Centre }\end{array}$ & $\begin{array}{l}\text { Created 25 August 2000; brought under CAC Act on } 1 \\
\text { July 2008 }\end{array}$ \\
\hline NBN Co. Ltd & $\begin{array}{l}\text { Created } 9 \text { April 2009 to develop the national broadband } \\
\text { network; intended to have mixed public-private } \\
\text { ownership }\end{array}$ \\
\hline Tuggeranong Office Park Ltd & $\begin{array}{l}\text { Created 22 March 1989; brought under CAC Act on 3 } \\
\text { December 2008 }\end{array}$ \\
\hline Outback Stores Pty Ltd & $\begin{array}{l}\text { Previously a subsidiary of Indigenous Business Australia; } \\
\text { created as a separate company under CAC Act on } 1 \\
\text { March 2010 }\end{array}$ \\
\hline
\end{tabular}

Table 4.3.4 Abolitions (not recorded in creations and conversions list above)

\begin{tabular}{|l|l|}
\hline Statutory authorities & \\
\hline Dairy Adjustment Authority & Act 123/2008 \\
\hline Prescribed authorities (FMA Act) & \\
\hline Biosecurity Australia & De-prescribed on 1 July 2009 \\
\hline Companies & \\
\hline Health Services Australia Ltd & $\begin{array}{l}\text { Became subsidiary of Medibank Private Ltd } \\
\text { on 1 April 2009 }\end{array}$ \\
\hline Maritime Industry Finance Co. Ltd & Delisted 24 April 2008 \\
\hline Net Alert Ltd & Delisted 18 December 2008 \\
\hline Telstra Sale Co. Ltd & Delisted 27 May 2009 \\
\hline Three Innovation Investment Fund (IIF) firms & \\
\hline
\end{tabular}

